crossing the ridges they rise in minute scabrous plications. The aperture is enamelled with a tinge of ruddy colour.

The upper figure represents the shell of the natural size. In the lower figures it is enlarged to show the scabrous plications.

March 25, 1862.

Dr. J. E. Gray, V.P., in the Chair.

'The Secretary announced that Dr. G. Bennett, F.Z.S., had shipped a living Kagu (Rhinochetus jubatus) for the Society from Sydney on the 16th of January previous, and read the following extracts from a letter just received from that gentleman relating to the habits of this remarkable bird :-

" Of the two Kagus brought from New Caledonia alive, one died on the 4th of January, 1862, and on dissection proved to be a female. It was larger than the one now sent to England alive; and when that one dies (as the plumage and crest are similar, and both appeared to be fully grown, the only distinction being size) it would be interesting to ascertain the sex. The Kagu is a very interesting bird, readily domesticated. It is amusing to see them politely bowing their heads one to the other, elevating their crests at the same time, and then finish by coquetting about. They climb up the wires in front of their place of confinement just as the Red-billed Porphyrios. They often leap, aided by the wings, upon the stumps or low branches of trees; but they invariably roost on the ground, in an erect position, with the head buried between the shoulders or under the wing, and in confinement never seek any elevated position for roosting. In New Caledonia they are usually seen about the sea-coast, by the side of rivers; and although in some parts of the island they are very numerous, yet about the settlement of Port du France they are seldom seen more than from two to four together at the same time. When disturbed they only fly to the height of a few feet, and escape into the thick brushwood. They are eaten by the natives. A lady just returned from New Caledonia informs me that a pair have been kept tame at Port du France for nearly three years, and are wellknown roamers of the streets of that settlement. When a dog approaches them, they elevate their crests and flap their wings to drive it away. They are usually to be seen about those places where the men are digging, approaching them fearlessly for the sake of procuring worms or grubs that are turned up from the ground by the hoe or spade. The same lady describes a noise they make in their wild state, when concealed among the reeds or bushes, as resembling that of a young puppy crying for its mother."

The following extract was read from a letter addressed by Colonel Abbott to George O. Wray, Esq., and communicated by the latter gentleman to the Secretary :- 
"In March, 1838, as near as I can recollect, near the village of Pur-Buddah, distant $1 \frac{1}{2}$ mile from the town of Akyab in Arracan, two Sepoys of the Arracan Local Battalion captured under a rock a large female Boa, some 12 feet in length, and abstracted with her a nest of eggs forty-eight in number. Both Snake and eggs were pre. sented to me by a friend, who knew that I was interested. in such things. My object now was to secure this prize, and see what would result from the detention. Unfortunately I was taken seriously ill, and neglected to keep notes on the subject, and all I now state is from recollection. The Python was in my possession for upwards of two months and a half, and was constantly coiled around her eggs, refusing food in various forms, living and dead, viz., fowls, rats, and frogs. I then quitted Arracan on sick-leave and came to Calcutta, bringing the Snake and eggs with me, and made them over to Dr. Pearson (since dead) and Dr. Evans. The Snake was in my posses. sion, as I said before, about ten weeks in the province and ten days (more or less) in Calcutta, and nearly a week on the voyage up to Calcutta, as we went to Chittagong: this will bring the eggs and Snake to be known to me three months; and the eggs were still not hatched.

"On visiting the Museum and finding the eggs in the condition I sent them in, curiosity led us to detach an egg from the mass; and looking at it carefully it was supposed to be bad, as it exhibited marks of green mildew and soil, and there was no motion in it. We then determined to open it with a knife, and to our surprise we extracted a fully formed live young one, active and strong, which would, I have no doubt, have lived had it been allowed. I left Calcutta shortly after this, and do not know what became of the Boa and remaining eggs ; but, should further information be required, I would suggest that application be made to Mr. Blyth, if still in Calcutta, or to the Curator of the Asiatic Museum of Calcutta."

The following extracts were read from a letter addressed to Dr. Gray by Mr. Henry Blandford, respecting some Mollusks observed in Ceylon :-

"I have nothing particular to communicate respecting the Aulopoma, beyond what you have yourself noticed-viz., that the operculum is frequently drawn well into the whorl, the aperture of which is perfectly closed by the flexible edges of the former.

"There is but oue species of Aulopoma in Ceylon, varying considerably in the size and in the height of the spire, and also, to some extent, in colouring. But these are mere variations, and there are not even any sharply defined varieties. I enclose you a sketch of the animal.

"The Aulopomata are found under damp leaves at the roots of trees, especially some of the Figs, such as Ficus elastica. In this selection of damp shady places they resemble most of the Cyclophoroid genera.

"The Paludomus chilinoïdes, of which you have two specimens, is very common in the plains of Ceylon and up to about 2000 feet. 
It affects sluggish streams, tanks, and paddy-fields; in this respect it differs from the Tanuli and Philopotami, which greatly prefer swiftly running water. $P$. spiralis (from the north province of Ceylon) and $\boldsymbol{P}$. acutus (from Madras, Trichinopoly, \&c.) have similar habits to $P$. chilinoïdes, and are probably merely well-marked varieties of the latter.

"Helix (Nanina) ceylanica is a local variety of $H$. bistrialis. The former inhabits the hills up to about 3000 feet; the latter the plains of the north provinces of Ceylon, and a great part of Southern India. I send you a sketch of the animal of H. (Nanina) bistrialis."

The following papers were read :-

1. Characters of Nine New Species of Birds received in collections from Bogota. By P. L. Sclater, M.A., Ph.D., F.R.S., Secretary to the Society.

\section{(Plate XI.)}

I have lately had an opportunity of examining several large collections of bird-skins from Bogota, containing altogether some three or four thousand individuals. 'The greater number of the species to which these belong are now well known in Europe, from their repeated importation in Bogotan collections; but I have found a few, principally among the more little-known groups, which appear to have been altogether overlooked or hitherto not collected. I beg leave to submit to the Society the following descriptions of these species.

Fam. Turdide.

\section{Turdus ephippialis.}

Supra cinerens, alis extus, nisi in primariorum parte terminali, et interscapulio rufescente indutis: subtus pallide cinereus : gutture albo, maculis triangularibus fuscis striato: ventre imo et crisso albis : tectricibus subalaribus et remigun parte interna pallide castaneis : rostro plumbeo: tomiis pallescentibus : pedibus fuscis.

Long. tota $8 \cdot 5$, alæ $4 \cdot 7$, caudæ $4 \cdot 2$ poll. Angl. et dec.

Hab. In Nov. Granada int.

Mus. P. L. S.

Obs. Affinis Turdo albiventri ex Cayenna, et ptilosi fere simili, sed interscapulio et alis extus rufescentibus, et subalaribus castaneis facile dignoscendus.

I may remark that $I$ have now received from the Berlin Museum a Thrush marked Turdus amaurochalinus,-a species with which I was not acquainted when I prepared my Synopsis of the American Thrushes, already printed in the Society's 'Proceedings.' * This bird is certainly undistiuguishable from what I consider to be Turdus albiventris of Spix, of which I have examples from Cayenne, Brazil, Bolivia, and Ecuador. My Turdus ignobilis of the highlands of New

* See P. Z. S. 1859 , p. 321 . 